\title{
Marek Szydło
}

Uniwersytet Wrocławski

e-mail: marek.szydlo@uwr.edu.pl

ORCID: 0000-0002-3776-2020

\section{CYWILNOPRAWNA SANKCJA DOTYKAJĄCA UMOWE ZAWARTĄ Z POMINIECCIEM USTAWY PRAWO ZAMÓWIEŃ PUBLICZNYCH W ŚWIETLE PRAWA UNIJNEGO*}

\section{CIVIL LAW SANCTION CONCERNING CONTRACTS CONCLUDED WITH OMISSION OF THE ACT ON PUBLIC PROCUREMENT IN LIGHT OF THE EU LAW}

DOI: $10.15611 / \mathrm{pn} .2018 .540 .17$

JEL Classification: K23

Streszczenie: Niniejszy artykuł ma na celu wykazanie, że ewentualne przyjęcie przez orzecznictwo polskich sądów lub Krajowej Izby Odwoławczej albo przez praktykę stosowania Pzp, że umowa będąca zamówieniem publicznym zawarta z całkowitym pominięciem przepisów Pzp dotknięta jest cywilnoprawną sankcją bezwzględnej nieważności, nie byłoby niezgodne z prawem Unii Europejskiej. Przeciwnie, mieściłoby się to w zakresie swobody organów państwa członkowskiego (w tym wypadku Polski) w odniesieniu do implementowania (wdrażania) w prawie krajowym odnośnych przepisów unijnych dyrektyw normujących sankcje umów zawartych z naruszeniem unijnych dyrektyw o zamówieniach publicznych.

Słowa kluczowe: Prawo zamówień publicznych, sankcja nieskuteczności umowy, nieważność bezwzględna.

Summary: This article is targeted at indicating that potential approval by Polish courts or the National Chamber of Appeal or through the applied practice of Public Procurement Law of the fact that a given contract, constituting public order, concluded with entire omission of the provisions of Public Procurement Law is burdened with civil law sanction of absolute invalidity would not comply with the European Union law. On the contrary, it would fit in the scope of freedom of member state bodies (here: Poland) with regards to implementing

* Artykuł powstał w ramach projektu badawczego SONATA BIS finansowanego ze środków Narodowego Centrum Nauki, na podstawie decyzji nr DEC-2014/14/E/HS5/00845, umowa nr UMO$-2014 / 14 / \mathrm{E} / \mathrm{HS} 5 / 00845$. 
into the national law of relevant EU Directive provisions, normalizing sanctions of contracts concluded in breach of EU directives on public procurement.

Keywords: Public Procurement Law, sanction of contract ineffectiveness, absolute invalidity.

\section{Wstęp}

Polska ustawa Prawo zamówień publicznych ${ }^{1}$ (dalej: Pzp) nie zawiera przepisu wyraźnie określającego cywilnoprawną sankcję mającą zastosowanie wobec umowy, która w sensie materialnoprawnym jest zamówieniem publicznym (tzn. spełnia przesłanki z art. 2 pkt 13 w zw. z art. 2 pkt 2, 8, 10, 11 i 12 Pzp) i która została zawarta $\mathrm{z}$ całkowitym pominięciem przepisów Pzp, a więc bez przestrzegania jakichkolwiek w ogóle przepisów Pzp normujących tryb zawierania umów w sprawach zamówień publicznych. Wykładnia przepisów Pzp prowadzi zazwyczaj komentatorów do wniosku, że wspomniana wyżej umowa jest unieważnialna na podstawie art. 146 ust. 1 pkt 2 Pzp (przepis ten stanowi, że „Umowa podlega unieważnieniu, jeżeli zamawiający (...) nie zamieścił ogłoszenia o zamówieniu w Biuletynie Zamówień Publicznych albo nie przekazał ogłoszenia o zamówieniu Urzędowi Publikacji Unii Europejskiej”) lub na podstawie art. 146 ust. 6 Pzp („Prezes Urzędu [Zamówień Publicznych] może wystąpić do sądu o unieważnienie umowy w przypadku dokonania przez zamawiającego czynności lub zaniechania dokonania czynności z naruszeniem przepisu ustawy, które miało lub mogło mieć wpływ na wynik postępowania"), aczkolwiek istnieje też wiele dobrych argumentów prawniczych na rzecz tezy, że taka umowa jest po prostu bezwzględnie nieważna co można stwierdzić opierając się na art. 58 § 1 Kodeksu cywilnego ${ }^{2}$ (dalej: k.c.) ${ }^{3}$. Niniejszy artykuł ma na celu wykazanie, że ewentualne przyjęcie przez orzecznictwo polskich sądów lub Krajowej Izby Odwoławczej albo przez praktykę stosowania Pzp, że umowa będąca zamówieniem publicznym zawarta $\mathrm{z}$ całkowitym pominięciem przepisów Pzp dotknięta jest cywilnoprawną sankcją bezwzględnej nieważności, nie byłoby niezgodne z prawem Unii Europejskiej, czy też innymi słowy - mieściłoby się to w zakresie swobody organów państwa członkowskiego (w tym wypadku Polski) w odniesieniu do implementowania (wdrażania) w prawie krajowym odnośnych przepisów unijnych dyrektyw normujących sankcje umów zawartych z naruszeniem unijnych dyrektyw o zamówieniach publicznych.

W prawie Unii Europejskiej obowiązują następujące dyrektywy normujące procedury odwoławcze w dziedzinie udzielania zamówień publicznych: dyrekty-

${ }^{1}$ Ustawa z dnia 29 stycznia 2004 r., tekst jedn. Dz. U. z 2018 r., poz. 1986 ze zm.

${ }^{2}$ Ustawa z dnia 23 kwietnia 1964 r., tekst jedn. Dz. U. z 2018 r., poz. 1025 ze zm.

${ }^{3}$ Stosowną dyskusję i argumentację w tym względzie zob. szerzej w opracowaniu M. Szydło i W. Szydło pt. Bezwzględna nieważność umów zawartych bez stosowania ustawy Prawo zamówień publicznych zamieszczonym w niniejszym czasopiśmie. 
wa $2007 / 66 / \mathrm{WE}^{4}$, dyrektywa $89 / 665 / \mathrm{EWG}^{5}$ oraz dyrektywa 92/13/EWG ${ }^{6}$. Przepisy dyrektyw 89/665/EWG i 92/13/EWG, w brzmieniu nadanym dyrektywą 2007/66/ WE, nakładają na państwa członkowskie obowiązek zapewniania, że w określonych w tych dyrektywach przypadkach umowa objęta zakresem zastosowania unijnych dyrektyw o zamówieniach publicznych - czyli umowa mieszcząca się w zakresie

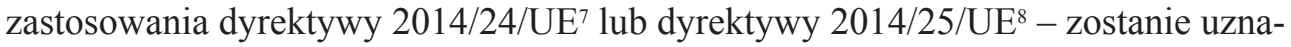
na za nieskuteczną (ineffective) przez organ odwoławczy niezależny od instytucji zamawiającej lub też nieskuteczność takiej umowy będzie wynikała z decyzji takiego organu odwoławczego (zob. art. 2d ust. 1 dyrektywy 89/665/EWG oraz art. 2d ust. 1 dyrektywy 92/13/EWG). Jednym z tych przypadków uzasadniających nieskuteczność umowy będącej zamówieniem publicznym jest w świetle unijnego prawa wtórnego sytuacja, w której instytucja zamawiająca udzieliła zamówienia publicznego (tj. zawarła umowę podlegającą dyrektywie 2014/24/UE lub dyrektywie 2014/25/UE) bez uprzedniej publikacji ogłoszenia o zamówieniu w Dzienniku Urzędowym Unii Europejskiej wbrew przepisom dyrektywy 2014/24/UE lub dyrektywy 2014/25/UE (art. 2d ust. 1 lit. a) dyrektywy 89/665/EWG oraz art. 2d ust. 1 lit. a) dyrektywy 92/13/EWG). Wśród tychże przypadków nieskuteczności umowy dyrektywy 89/665/EWG oraz 92/13/EWG nie wymieniają wyraźnie przesłanki w postaci udzielenia zamówienia publicznego lub zawarcia umowy z pominięciem przepisów dyrektywy 2014/24/UE lub dyrektywy 2014/25/UE, tj. unijnych dyrektyw o zamówieniach publicznych. Równocześnie pkt 13 preambuły do dyrektywy 2007/66/WE stanowi, co następuje: „Aby zwalczać bezprawne bezpośrednie udzielanie zamówień, które zostało uznane przez Trybunał Sprawiedliwości za najpoważniejsze naruszenie prawa wspólnotowego w dziedzinie zamówień publicznych ze strony instytucji zamawiającej lub podmiotu zamawiającego, należy przewidzieć skuteczne, proporcjonalne i odstraszające sankcje. Dlatego umowa zawarta na podstawie bezprawnego bezpośredniego udzielenia zamówienia powinna być z zasady

${ }^{4}$ Dyrektywa 2007/66/WE Parlamentu Europejskiego i Rady z dnia 11 grudnia 2007 r. zmieniająca dyrektywy Rady 89/665/EWG i 92/13/EWG w zakresie poprawy skuteczności procedur odwoławczych w dziedzinie udzielania zamówień publicznych, Dz. Urz. WE 2007, L 335/31.

${ }^{5}$ Dyrektywa Rady 89/665/EWG z dnia 21 grudnia 1989 r. w sprawie koordynacji przepisów ustawowych, wykonawczych i administracyjnych odnoszących się do stosowania procedur odwoławczych w zakresie udzielania zamówień publicznych na dostawy i roboty budowlane (Dz. Urz. EWG 1989, L 395/33), zmieniona dyrektywą 2007/66/WE.

${ }^{6}$ Dyrektywa 92/13/EWG z dnia 25 lutego 1992 r. koordynująca przepisy ustawowe, wykonawcze i administracyjne odnoszące się do stosowania przepisów wspólnotowych w procedurach zamówień publicznych podmiotów działających w sektorach gospodarki wodnej, energetyki, transportu i telekomunikacji (Dz. Urz. EWG 1992, L 76/14), zmieniona dyrektywą 2007/66/WE.

${ }^{7}$ Dyrektywa Parlamentu Europejskiego i Rady 2014/24/UE z dnia 26 lutego 2014 r. w sprawie zamówień publicznych, uchylająca dyrektywę 2004/18/WE, Dz. Urz. UE 2014, L 94/65.

${ }^{8}$ Dyrektywa Parlamentu Europejskiego i Rady 2014/25/UE z dnia 26 lutego 2014 r. w sprawie udzielania zamówień przez podmioty działające w sektorach gospodarki wodnej, energetyki, transportu i usług pocztowych, uchylająca dyrektywę 2004/17/WE, Dz. Urz. UE 2014, L 94/243. 
uważana za nieskuteczną. Nieskuteczność nie powinna być automatyczna, lecz powinna być stwierdzona przez niezależny organ odwoławczy lub wynikać z podjętej przez ten organ decyzji”.

W toku dalszych rozważań zostaną wykazane dwie następujące tezy. Po pierwsze, w ramach unijnej sankcji nieskuteczności umowy w sprawie zamówienia publicznego (o której jest mowa we wspomnianych wyżej unijnych dyrektywach 2007/66/ WE, 89/665/EWG i 92/13/EWG) mieści się również polska sankcja bezwzględnej nieważności umowy przewidziana w art. $58 \S 1$ k.c. Polska jako państwo członkowskie ma zatem prawo kwalifikować umowy w sprawach zamówień publicznych podlegające dyrektywom 2014/24/UE i 2014/25/UE i zawarte bez przestrzegania ich postanowień jako umowy bezwzględnie nieważne w rozumieniu art. $58 \S 1$ k.c., czym wypełni swój obowiązek uznawania takich umów za nieskuteczne, tak jak wymagają tego dyrektywy 2007/66/WE, 89/665/EWG i 92/13/EWG. Po drugie, nawet $\mathrm{w}$ razie uznania, że sankcja z art. $58 \S 1$ k.c. nie mieści się w ramach unijnej sankcji „nieskuteczności” umowy, polski ustawodawca i tak ma w świetle przepisów wymienionych unijnych dyrektyw prawo do tego, by zastosować w omawianym tutaj zakresie sankcję surowszą niż unijna sankcja „nieskuteczności” umowy, a którą to surowszą sankcją jest sankcja bezwzględnej nieważności umowy wynikająca $\mathrm{z}$ art. $58 \S 1$ k.c.

\section{Polska sankcja bezwzględnej nieważności umowy jako przejaw unijnej sankcji nieskuteczności umowy}

Sankcja nieskuteczności umowy w rozumieniu dyrektyw 89/665/EWG, 92/13/ EWG oraz 2007/66/WE jest na tyle ogólnym i szerokim konceptem, że również polska sankcja bezwzględnej nieważności umowy przewidziana w art. $58 \S 1$ k.c. może być uznawana za przejaw (postać) sankcji nieskuteczności umowy w rozumieniu przyjętym w tych dyrektywach. W istocie bowiem sankcja nieskuteczności umowy ustanowiona w dyrektywach 89/665/EWG, 92/13/EWG i 2007/66/WE ma w zakresie swojej unijnej konstrukcji prawnej charakter jedynie bardzo ramowy i w świetle wyraźnych przepisów tych dyrektyw wszelkie konsekwencje prawne tej nieskuteczności powinno określać prawo krajowe. W dyrektywie 2007/66/WE jedynie w sposób bardzo ogólny określono istotę tejże sankcji nieskuteczności, postanawiając, że celem uznania umowy za nieskuteczną jest to „by prawa i obowiązki stron tej umowy przestały być egzekwowane i wykonywane"9. Natomiast wszelkie konsekwencje prawne tak pojmowanej nieskuteczności umowy powinno określać prawo krajowe, o czym stanowi zarówno pkt $21 \mathrm{zd}$. 2 preambuły do dyrektywy 2007/66/WE, jak i art. 2d ust. 2 zd. 1 dyrektywy 89/665/EWG oraz art. 2d ust. 2 zd. 1 dyrektywy 92/13/EWG (te ostatnie przepisy dyrektyw 89/665/EWG i 92/13/ EWG stanowią, że „Konsekwencje wynikające z uznania umowy za nieskuteczną

\footnotetext{
${ }^{9}$ Pkt 21 zd. 1 preambuły do dyrektywy 2007/66/WE.
} 
przewidziane są przez prawo krajowe"). Powyższe oznacza, że dyrektywy 89/665/ EWG, 92/13/EWG oraz 2007/66/WE określają jedynie ogólny cel sankcji nieskuteczności umowy w sprawie zamówienia publicznego, a ma on polegać na tym, by prawa i obowiązki stron umowy w sprawie zamówienia publicznego ,przestały być egzekwowane i wykonywane" 10 , a więc by te prawa i obowiązki przestały prawnie wiązać strony umowy w sprawie zamówienia publicznego. Przy czym w dyrektywach 89/665/EWG i 92/13/EWG (znowelizowanych dyrektywą 2007/66/WE) wyraźnie postanowiono, że „Prawo krajowe może przewidywać wsteczne anulowanie wszystkich zobowiązań umownych lub ograniczyć zakres anulowania do tych zobowiązań, które należy jeszcze wykonać" (art. 2d ust. 2 zd. 2 dyrektywy 89/665/EWG oraz art. 2 d ust. 2 zd. 2 dyrektywy 92/13/EWG). Dyrektywy 89/665/EWG i 92/13/ EWG wyraźnie zatem dozwalają państwom członkowskim na to, by sankcja nieskuteczności umowy w rozumieniu tych dyrektyw - czyli sankcja polegająca na tym, że prawa i obowiązki wynikające $\mathrm{z}$ umowy $\mathrm{w}$ sprawie zamówienia publicznego przestają być dla stron tej umowy prawnie wiążące i egzekwowalne - była stosowana z mocą prawną ex tunc, czyli z mocą wsteczną od momentu zawarcia danej umowy W sprawie zamówienia publicznego ${ }^{11}$. W tak ogólnie zakreślonej sankcji nieskuteczności umowy w rozumieniu dyrektyw 89/665/EWG, 92/13/EWG oraz 2007/66/WE mieści się również polska sankcja bezwzględnej nieważności umowy w rozumieniu art. $58 \S 1$ k.c. Ta ostatnia sankcja ma bowiem dwie omówione dotychczas cechy sankcji nieskuteczności umowy w rozumieniu dyrektyw 89/665/EWG, 92/13/EWG oraz 2007/66/WE: po pierwsze, cechę polegającą na tym, że prawa i obowiązki stron umowy w sprawie zamówienia publicznego przestają być dla stron tej umowy prawnie wiążące i egzekwowalne oraz, po drugie, cechę skuteczności tej sankcji ex tunc, czyli z mocą wsteczną od momentu zawarcia danej umowy ${ }^{12}$.

Kwalifikacji polskiej sankcji bezwzględnej nieważności umowy w sprawie zamówienia publicznego przewidzianej w art. $58 \S 1$ k.c. jako sankcji odpowiadającej cechom sankcji nieskuteczności umowy w rozumieniu dyrektyw 89/665/EWG, 92/13/EWG oraz 2007/66/WE nie sprzeciwiają się bynajmniej słowa wypowiedziane przez prawodawcę unijnego w punkcie 13 zd. 3 preambuły do dyrektywy 2007/66/WE, w świetle których „Nieskuteczność nie powinna być automatyczna,

${ }^{10}$ Pkt 21 zd. 1 preambuly do dyrektywy 2007/66/WE.

${ }^{11}$ Wiele państw członkowskich skorzystało z tej możliwości i rzeczywiście przewidują one w swoim prawie wewnętrznym nieskuteczność umów w sprawach zamówień publicznych działającą z mocą ex tunc: F. Wilman, Private Enforcement of EULaw Before National Courts. The EULegislative Framework, Cheltenham 2015, s. 87; M. Burgi,EU Procurement Rules - AReportabout the German Remedies System, [w:] Enforcement of the EU Public Procurement Rules, red. S. Treumer, F. Lichère, Copenhagen 2011, s. 138 i n.

${ }^{12}$ Ogólnie na temat cech sankcji bezwzględnej nieważności umowy w rozumieniu art. 58 § 1 k.c. zob. np. Z. Radwański, Sankcje wadliwej czynności prawnej, [w:] System prawa prywatnego. Tom 2. Prawo cywilne - część ogólna, red. Z. Radwański, Warszawa 2002, s. 428-429; M. Safjan, Art. 58, [w:] Kodeks cywilny. Tom I. Komentarz do artykułów 1-44910, red. K. Pietrzykowski, Warszawa 2011, s. 337 i n.; M. Gutowski, Nieważność czynności prawnej, Warszawa 2017, s. 391 i n. 
lecz powinna być stwierdzona przez niezależny organ odwoławczy lub wynikać z podjętej przez ten organ decyzji". To ostatnie stwierdzenie prawodawcy unijnego należy rozumieć w ten sposób, że nieskuteczność umowy w sprawie zamówienia publicznego przewidziana w dyrektywie 2007/66/WE (oraz w dyrektywach 89/665/ EWG i 92/13/EWG) nie może być w krajowym porządku prawnym stanem, który jest tworzony wyłącznie z mocy postanowień samego prawa, lecz musi to być stan, który da się w sposób co najmniej deklaratoryjny potwierdzić przez niezależny organ odwoławczy, którym może być również sąd. Innymi słowy, nawet jeżeli sankcja krajowa wywołuje „nieskuteczność” umowy działającą z mocy samego prawa, ale jednocześnie istnieje mechanizm krajowy pozwalający niezależnemu organowi stwierdzać tę nieskuteczność w sposób deklaratoryjny, to wówczas taka sankcja nie jest już sankcją ,automatyczną" w rozumieniu punktu $13 \mathrm{zd} .3$ preambuły do dyrektywy 2007/66/WE. W powołanym wyżej pkt $13 \mathrm{zd}$. 3 preambuły do dyrektywy 2007/66/WE prawodawcy unijnemu chodziło zatem o to, by strony umowy w sprawie zamówienia publicznego zawartej z naruszeniem unijnych procedur o zamówieniach publicznych, a także wszystkie zainteresowane osoby trzecie nie pozostawały w niepewności odnośnie do tego, czy dana umowa jest skuteczna czy też nie (a niepewność taka istniałaby wówczas, gdyby krajowa sankcja nieskuteczności umowy aktualizowała się wyłącznie z mocy samego prawa), lecz aby istniał niezależny organ, np. sąd, który jest kompetentny do tego, by stwierdzić, że dana umowa jest nieskuteczna lub by zarządzić taka nieskuteczność. Z literalnych sformułowań zawartych w pkt 13 zd. 3 preambuly do dyrektywy 2007/66/WE jasno przy tym wynika, że decyzja właściwego niezależnego organu, w tym sądu, odnośnie do nieskuteczności umowy może mieć charakter deklaratoryjny, gdyż może się ona przejawiać w ,stwierdzeniu” nieskuteczności umowy ${ }^{13}$. Jeżeli zatem w danym krajowym porządku prawnym sąd krajowy jest na mocy przepisów prawa krajowego uprawniony do tego, by w sposób deklaratoryjny potwierdzać bezwzględną nieważność umowy w sprawie zamówienia publicznego zawartej z naruszeniem unijnych procedur o zamówieniach publicznych, tak iż wskutek takiego deklaratoryjnego potwierdzenia prawa i obowiązki stron tej umowy stają się prawnie niewiążące i nieegzekwowalne $\mathrm{z}$ mocą ex tunc, to takie rozwiązanie jest jak najbardziej zgodne z dyrektywami 89/665/EWG, 92/13/EWG i 2007/66/WE oraz stanowi ono przejaw implementacji w danym krajowym porządku prawnym sankcji nieskuteczności umowy przewidzianej w tych dyrektywach (należy tylko pamiętać, że w takich przypadkach sąd krajowy nie może stwierdzać nieważności umowy w sprawie zamówienia publicznego w przypadkach opisanych w art. 2d ust. 4 i 5 dyrektywy 89/665/EWG oraz w art. 2d ust. 4 i 5 dyrektywy 92/13/EWG, gdyż te ostatnie przepisy, wykluczające prawną

${ }^{13}$ Zob. też art. art. 2 d ust. 1 in principio dyrektywy 89/665/EWG oraz art. 2 d ust. 1 in principio dyrektywy 92/13/EWG, które stanowią co następuje: „Państwa członkowskie zapewniają, by umowa została uznana za nieskuteczną przez organ odwoławczy niezależny od podmiotu zamawiającego lub by jej nieskuteczność wynikała z decyzji takiego organu odwoławczego". 
dopuszczalność uznawania umów za nieskuteczne w sytuacjach określonych w tych przepisach, mają charakter obligatoryjny dla państw członkowskich ${ }^{14}$ ). Jest bowiem normatywnym faktem, że sankcja nieskuteczności umowy w rozumieniu dyrektyw 89/665/EWG, 92/13/EWG oraz 2007/66/WE została w tych dyrektywach ukształtowana w sposób jedynie bardzo ogólny i ramowy, przy pozostawieniu państwom członkowskim bardzo daleko idącej swobody odnośnie do ukształtowania jej reżimu prawnego i wszelkich konsekwencji prawnych. W takim układzie państwa członkowskie mogą wprowadzać w swoim prawie krajowym sankcje prawne dotykające umów w sprawach zamówień publicznych (zawartych z pominięciem lub naruszeniem unijnych procedur o zamówieniach publicznych), które mają bardzo różny kształt i reżim prawny ${ }^{15}$, byleby tylko sankcje te spełniały trzy następujące cechy: 1) w wyniku zastosowania danej sankcji prawa i obowiązki stron umowy w sprawie zamówienia publicznego stają się prawnie niewiążące i nieegzekwowalne ${ }^{16} ; 2$ ) dana sankcja działa wobec danej umowy ex tunc lub ex nunc ${ }^{17}$; 3) w danym państwie istnieje niezależny od stron organ publiczny, np. sąd, który ma kompetencję do tego, by w sposób deklaratoryjny potwierdzić nieskuteczność umowy lub by w sposób konstytutywny uznać daną umowę za nieskuteczną ${ }^{18}$.

W takim układzie należy uznać za bezsporne to, że również polska sankcja bezwzględnej nieważności umowy w sprawie zamówienia publicznego przewidziana w art. $58 \S 1$ k.c. - mogąca mieć zastosowanie do umów w sprawach zamówień publicznych zawartych bez stosowania ustawy Pzp - ma w pełni scharakteryzowane wyżej cechy sankcji nieskuteczności umowy w rozumieniu dyrektyw 89/665/ EWG, 92/13/EWG oraz 2007/66/WE. Mianowicie sankcja bezwzględnej nieważności umowy przewidziana $\mathrm{w}$ art. $58 \S 1$ k.c. - a stosowana do umów w sprawach zamówień publicznych zawartych bez stosowania ustawy Pzp - powoduje w swoich skutkach prawnych, że prawa i obowiązki stron umowy w sprawie zamówienia publicznego stają się prawnie niewiążące i nieegzekwowane (tak jak wymaga tego pkt 21 zd. 1 dyrektywy 2007/66/WE), a przy tym dzieje się tak z mocą ex tunc, czyli od momentu zawarcia danej umowy (tak jak na to dozwalają art. 2 d ust. 2 zd. 2 dyrektywy 89/665/EWG oraz art. 2d ust. 2 zd. 2 dyrektywy 92/13/EWG). Ponadto prawo polskie przewiduje kompetencję dla sądu powszechnego do wydania orzeczenia w sposób deklaratoryjny potwierdzającego bezwzględną nieważność danej umowy w sprawie zamówienia publicznego (zob. art. 189 Kodeksu postępowania

${ }^{14}$ Zob. wyrok TSUE w sprawie C-19/13, Ministero dell'Interno przeciwko Fastweb SpA, ECLI: EU:C:2014:2194, pkt 42-54.

${ }^{15}$ Pkt 21 zd. 2 preambuly do dyrektywy 2007/66/WE; art. 2d ust. 2 zd. 1 dyrektywy 89/665/EWG; art. 2 d ust. 2 zd. 1 dyrektywy 92/13/EWG.

${ }^{16}$ Pkt 21 zd. 1 preambuly do dyrektywy 2007/66/WE.

${ }^{17}$ Art. 2 d ust. 2 zd. 2 dyrektywy 89/665/EWG; art. 2d ust. 2 zd. 2 dyrektywy 92/13/EWG.

${ }^{18} \mathrm{Pkt} 13$ zd. 3 preambuły do dyrektywy 2007/66/WE; art. 2d ust. 1 in principio dyrektywy 89/665/ EWG; art. 2d ust. 1 in principio dyrektywy 92/13/EWG. 
cywilnego ${ }^{19}$, co przyczynia się do usunięcia stanu wszelkiej niepewności prawnej odnośnie do statusu prawnego danej umowy, tj. jej ważności lub nieważności (tak jak tego wymaga pkt $13 \mathrm{zd}$. 3 preambuly do dyrektywy 2007/66/WE oraz art. 2d ust. 1 in principio dyrektywy 89/665/EWG i art. 2 d ust. 1 in principio dyrektywy 92/13/EWG). W tym ostatnim sensie polska sankcja bezwzględnej nieważności umowy przewidziana w art. $58 \S 1$ k.c. nie działa w sposób automatyczny, tzn. nie działa w sposób ,automatyczny” w rozumieniu przyjętym w pkt 13 zd. 3 preambuły do dyrektywy 2007/66/WE.

Ów unijny zakaz „automatycznego” działania sankcji nieskuteczności umowy przewidziany w pkt 13 zd. 3 preambuły do dyrektywy 2007/66/WE ma specyficzne znaczenie prawne, gdyż jest on połączony w unijnym prawie wtórnym z wymogiem, by nieskuteczność ta była co najmniej w sposób deklaratoryjny potwierdzana przez niezależny organ, np. sąd. Uwzględniając pożądane cele tego ostatniego wymogu (tj. wyeliminowanie niepewności prawnej co do skuteczności lub nieskuteczności danej umowy, ograniczenie występowania w tym zakresie sporów prawnych), należy uznać, że ów zakaz ,automatycznego” działania sankcji nieskuteczności umowy przewidziany w pkt 13 zd. 3 preambuly do dyrektywy 2007/66/WE ma w prawie unijnym specyficzne znaczenie prawne i nie może być on wprost utożsamiany z zakazem stosowania przez państwa członkowskie jakiejś konkretnej instytucji prawnej prawa krajowego, np. z zakazem stosowania cywilnoprawnej sankcji bezwzględnej nieważności umowy znanej prawu polskiemu. Prawodawcy unijnemu, kierującemu się wskazanymi wyżej celami, chodziło jedynie o to, by nieskuteczność umowy w sprawie zamówienia publicznego nie działała wyłącznie z mocy samego prawa, lecz by istniał zawsze właściwy i niezależny organ, który taką nieskuteczność działającą z mocy samego prawa będzie mógł co najmniej w sposób deklaratoryjny potwierdzić.

Polska sankcja bezwzględnej nieważności umowy przewidziana w art. $58 \S 1$ k.c. bynajmniej nie cechuje się takim zakazanym automatyzmem (w rozumieniu przyjętym w pkt 13 zd. 3 preambuły do dyrektywy 2007/66/WE). Co prawda w prawie polskim przyjmuje się, że sankcja bezwzględnej nieważności wywiera skutki z mocy samego prawa, nawet bez konieczności wydawania jakichkolwiek orzeczeń przez są ${ }^{20}$, niemniej jednak z praktycznego punktu widzenia ta bezwzględna nieważność czynności prawnej ma tak naprawdę rzeczywiste znaczenie dla jej stron oraz dla osób trzecich dopiero z momentem deklaratoryjnego potwierdzenia faktu tej nieważności przez sąd. We wcześniejszym okresie, tj. przed deklaratoryjnym potwierdzeniem bezwzględnej nieważności czynności prawnej przez sąd, zazwyczaj istnieje w kwestii ważności lub nieważności tej czynności prawnej daleko idąca niepewność oraz spory prawne. Niepewność ta oraz spory prawne zostają wyeli-

\footnotetext{
${ }^{19}$ Ustawa z dnia 17 listopada 1964 r., tekst jedn. Dz. U. z 2018 r., poz. 1360 ze zm.

${ }^{20}$ Zob. np. P. Machnikowski, Art. 58, [w:] Kodeks cywilny. Komentarz, red. E. Gniewek, Warszawa 2006, s. 131.
} 
minowane dopiero od momentu autorytatywnego potwierdzenia przez sąd, że dana czynność prawna jest bezwzględnie nieważna (oczywiście z mocą ex tunc). Takie rozwiązanie występujące $\mathrm{w}$ prawie polskim jest w pełni zgodne z ideą i konstrukcją sankcji nieskuteczności umowy unormowanej w dyrektywach 89/665/EWG, 92/13/ EWG i 2007/66/WE oraz z przewidzianym tam zakazem automatycznego działania omawianej nieskuteczności umowy, gdyż w dyrektywach tych prawodawcy unijnemu chodziło właśnie o to, by nieskuteczność umowy w sprawie zamówienia publicznego nie miała charakteru automatycznego w tym znaczeniu, że mogłoby dochodzić do daleko idącej niepewności prawnej i sporów prawnych odnośnie do tego, czy dana umowa jest skuteczna czy też nie. Omawiane dyrektywy unijne nie sprzeciwiają się temu, by sankcja nieskuteczności umowy uregulowana w krajowym porządku prawnym (i stanowiąca przejaw implementacji tej dyrektywy) wynikała z mocy samego prawa, ale z zastrzeżeniem, że sankcja ta nie może wynikać wyłącznie z mocy samego prawa, lecz musi istnieć niezależny organ, który ma kompetencję do stwierdzenia tej nieskuteczności. Dlatego też prawodawca unijny postanowił, że nieskuteczność umowy w sprawie zamówienia publicznego powinna być w sposób co najmniej deklaratoryjny potwierdzana przez niezależny organ, w tym przez sąd ${ }^{21}$. Tego rodzaju wymóg jest w prawie polskim w sposób oczywisty spełniony, w tym również w zakresie, w jakim sankcją nieskuteczności umowy w sprawie zamówienia publicznego (w rozumieniu przyjętym w dyrektywach unijnych) jest sankcja bezwzględnej nieważności umowy przewidziana w art. $58 \S 1$ k.c. O sankcji tej orzeka bowiem w sposób deklaratoryjny sąd (powszechny) i tak naprawdę to dopiero jego orzeczenie potwierdza w sposób autorytatywny z mocą erga omnes, że dana umowa w sprawie zamówienia publicznego jest bezwzględnie nieważna.

Raz jeszcze zatem trzeba powtórzyć, że sankcja nieskuteczności umowy w rozumieniu dyrektyw 89/665/EWG, 92/13/EWG oraz 2007/66/WE jest w tych dyrektywach unormowana w sposób bardzo ogólny i ramowy, przy jednoczesnym dozwoleniu państwom członkowskim na samodzielne kształtowanie reżimu prawnego i konsekwencji prawnych tej sankcji. Tak więc sankcja nieskuteczności umowy w rozumieniu powołanych dyrektyw nie ma na mocy tych dyrektyw jednolitego reżimu prawnego w skali całej UE. Dyrektywy te dozwalają na pluralizm krajowych rozwiązań prawnych w tym zakresie przy ustaleniu jedynie generalnych ram prawnych. Nie powinno zatem dziwić, że w praktyce rozwiązania prawne w poszczególnych państwach członkowskich są w tym zakresie bardzo zróżnicowane ${ }^{22}$. Tak jest również w Polsce - te rozwiązania prawne są zróżnicowane i mają dwojaki charakter: przejawem implementacji w prawie polskim sankcji nieskuteczności umo-

${ }^{21}$ Pkt 13 zd. 3 preambuły do dyrektywy 2007/66/WE; art. 2d ust. 1 in principio dyrektywy 89/665/ EWG; art. 2d ust. 1 in principio dyrektywy 92/13/EWG.

${ }^{22}$ Zob. przede wszystkim przegląd krajowych rozwiązań prawnych w zakresie sankcji nieskuteczności umowy w sprawie zamówienia publicznego dokonany w powołanej już wyżej pracy: Enforcement of the EU Public Procurement Rules, s. 136-141 (Niemcy), s. 191-195 (Rumunia), s. 220-225 (Wielka Brytania), s. 249-251 (Włochy), s. 273-284 (Dania), s. 314-319 (Francja). 
wy przewidzianej w unijnych dyrektywach jest zarówno sankcja unieważnialności umowy w sprawie zamówienia publicznego przewidziana w sytuacjach określonych w art. 144 i art. 146 ust. 1 Pzp, jak i sankcja bezwzględnej nieważności umowy przewidziana w art. $58 \S 1$ k.c. i stosowana poza sytuacjami wyraźnie przewidzianymi w art. 144 i art. 146 ust. 1 Pzp, w tym stosowana do umów w sprawach zamówień publicznych zawartych bez stosowania ustawy Pzp.

\section{Unijna sankcja nieskuteczności umowy jako standard minimalny}

Nawet gdyby przyjąć, że sankcja „nieskuteczności” umowy w sprawie zamówienia publicznego przewidziana w dyrektywach 89/665/EWG, 92/13/EWG oraz 2007/66/ WE oznacza w istocie sankcję unieważnialności (nieważności względnej) umowy $\mathrm{w}$ znaczeniu przyjmowanym $\mathrm{w}$ prawie polskim, to i tak polski ustawodawca jak najbardziej ma prawo do tego, by w odniesieniu do umów w sprawach zamówień publicznych zawartych bez stosowania ustawy Pzp (czyli zawartych z całkowitym pominięciem przepisów Pzp) i jednocześnie mieszczących się w zakresie zastosowania dyrektyw 2014/24/UE lub 2014/25/UE zastosować sankcję bezwzględnej nieważności umowy przewidzianą w art. $58 \S 1$ k.c. Jest tak zaś dlatego, gdyż sankcja prawna nieskuteczności umowy przewidziana w dyrektywach 89/665/EWG, 92/13/ EWG oraz 2007/66/WE i mająca być stosowana przez państwa członkowskie w odniesieniu do umów podlegających dyrektywom 2014/24/UE lub 2014/25/UE jest jedynie standardem minimalnym, a więc nie jest nakazana państwom członkowskim UE w sposób bezwzględny. Państwa członkowskie mogą w tym zakresie przewidywać sankcje surowsze. Możliwość stosowania przez państwa członkowskie surowszych sankcji wyraźnie przewiduje pkt 20 preambuły do dyrektywy 2007/66/WE, stanowiący co następuje: „Niniejsza dyrektywa nie powinna wykluczać stosowania surowszych sankcji zgodnie z prawem krajowym". Oznacza to, że prawo krajowe państw członkowskich jak najbardziej może przewidywać surowsze sankcje prawne na wypadek bezprawnego bezpośredniego udzielenia zamówienia publicznego, czyli na wypadek udzielenia zamówienia publicznego przy całkowitym pominięciu przepisów unijnych dyrektyw dotyczących zamówień publicznych lub przepisów prawa krajowego implementujących unijne dyrektywy dotyczące zamówień publicznych. Dyrektywy 89/665/EWG, 92/13/EWG oraz 2007/66/WE nie sprzeciwiają się zatem temu, by państwa członkowskie przyjęły i stosowały w tym zakresie w swoim prawie wewnętrznym sankcje surowsze, $\mathrm{w}$ tym szczególnie sankcję bezwzględnej nieważności umowy w sprawie zamówienia publicznego zawartej przy całkowitym pominięciu przepisów prawa krajowego implementujących unijne dyrektywy dotyczące zamówień publicznych.

Rozwiązanie polegające na przyjęciu na poziomie unijnym sankcji cywilnoprawnej o charakterze jedynie minimalnym, przy pozostawieniu państwom członkowskim swobody w zakresie ustalania w tym względzie sankcji surowszych, w tym 
cywilnoprawnej sankcji bezwzględnej nieważności umowy w sprawie zamówienia publicznego, jest rozwiązaniem w pełni trafnym, respektującym unijną zasadę subsydiarności (art. 5 ust. 1 i 3 Traktatu o Unii Europejskiej) ${ }^{23}$ oraz autonomię proceduralną państw członkowskich ${ }^{24}$. Ewentualne zaś przyjęcie w prawie unijnym rozwiązania polegającego na ustaleniu jednej sztywnej dla wszystkich państw członkowskich sankcji za bezprawne bezpośrednie udzielenie zamówienia publicznego nie tylko stanowiłoby przejaw naruszenia zasady subsydiarności oraz autonomii proceduralnej państw członkowskich, ale stanowiłoby jednocześnie przejaw nieakceptowalnego wkroczenia w krajowe standardy konstytucyjne związane z prawem jednostek do sądu oraz z organizacją wymiaru sprawiedliwości w państwach członkowskich. Te ostatnie kwestie mieszczą się zaś w zakresie respektowanej przez Unię Europejską tożsamości narodowej państw członkowskich, nierozerwalnie związanej z ich podstawowymi strukturami politycznymi i konstytucyjnymi. W tym względzie art. 4 ust. 2 zd. 1 Traktatu o Unii Europejskiej stanowi, że Unia Europejska szanuje tożsamość narodową państw członkowskich, nieodłącznie łączącą się z ich podstawowymi strukturami politycznymi i konstytucyjnymi ${ }^{25}$. W zakresie tej tożsamości narodowej mieszczą się m.in. tradycje prawne danego państwa członkowskiego związane z konstrukcją i aksjologią systemu sankcji cywilnoprawnych, a także przyjmowany w danym państwie członkowskim model sądowej ochrony prawnej jednostek będący wyrazem realizacji gwarancji konstytucyjnych w tym zakresie.

Pogląd, że w odniesieniu do sankcji za bezprawne bezpośrednie udzielenie zamówienia publicznego państwa członkowskie mogą stosować bardziej surowe sankcje niż sankcja nieskuteczności w rozumieniu dyrektywy 2007/66/WE, dyrektywy 89/665/EWG i dyrektywy 92/13/EWG jest podzielany również w doktrynie ${ }^{26}$.

${ }^{23}$ Zob. np. A.G. Toth, The principle of subsidiarity in the maastricht treaty, Common Market Law Review, 1992, vol. 29, s. 1079 i n.; N. Emiliou, Subsidiarity: an effective barrier against "the enterprises of ambition?, European Law Review, 1992, vol. 17, s. 383 i n.; D.Z. Cass, The word that saves Maastricht? The principle of subsidiarity and the division of powers within the European community, Common Market Law Review, 1992, vol. 29, s. 1107 i n.; T.C. Hartley, The foundations of European Union law, Oxford 2014, s. 122 i n.; G.A. Moens, J. Trone, Subsidiarity as Judicial and Legislative Review Principles in the European Union, [w:] Global Perspectives on Subsidiarity, red. M. Evans, A. Zimmermann, Dordrecht 2014, s. 157 i n.

${ }^{24}$ Por. D.-U. Galetta, Procedural Autonomy of EU Member States: Paradise Lost? A Study on the "Functionalized Procedural Competence" of EU Member States, Berlin-Heidelberg 2010, passim; C.N. Kakouris, Do the member states possess judicial procedural "autonomy”?, Common Market Law Review, 1997, vol. 34, nr 6, s. 1389 i n.

${ }^{25}$ Zob. szerzej A. von Bogdandy, S. Schill, Overcoming absolute primacy: Respect for national identity under the Lisbon Treaty, Common Market Law Review, 2011, vol. 48, s. 1417 i n.; D. Chalmers, G. Davies, G. Monti, European Union Law: Cases and Materials, Cambridge 2010, s. 219 i n.; L.F.M. Besselink, National and constitutional identity before and after Lisbon, Utrecht Law Review, 2010, vol. 6, s. 36 i n.; E. Cloots, National Identity in EU Law, Oxford 2015, passim.

${ }^{26}$ E. Matei, The Remedies Directive in public procurement, [w:] Research Handbook on EU Public Procurement Law, red. C. Bovis, Cheltenham 2016, s. 353-354; C.H. Bovis, EU Public Procurement Law, Cheltenham 2012, s. 237. 


\section{Dopuszczalne sposoby implementacji unijnej sankcji nieskuteczności umowy w prawie krajowym}

Nie można twierdzić, że sankcja nieskuteczności umowy przewidziana w dyrektywach 89/665/EWG, 92/13/EWG oraz 2007/66/WE została implementowana do prawa polskiego wyłącznie za pomocą ustawy z dnia 2 grudnia 2009 r. o zmianie ustawy Prawo zamówień publicznych oraz niektórych innych ustaw ${ }^{27}$, która to wprowadziła do ustawy Pzp przepisy o unieważnianiu umów w sprawach zamówień publicznych oraz że żadne inne środki legislacyjne nie służyły i nie mogły służyć implementacji do prawa polskiego sankcji nieskuteczności umowy uregulowanej w tych dyrektywach. Jest przecież rzeczą powszechnie uznawaną i przyjmowaną w doktrynie, w orzecznictwie TSUE oraz w praktyce stosowania prawa unijnego, że poszczególne instytucje prawne unormowane w przepisach unijnych dyrektyw mogą być implementowane do krajowego porządku prawnego nie tylko przez jedną specjalnie przeznaczoną do tego ustawę, ale również poprzez wiele różnych ustaw lub innych środków legislacyjnych lub przez pewne praktyki administracyjne. Co więcej, jest w pełni dozwolone, by państwa członkowskie w celu implementowania w prawie krajowym określonego rozwiązania prawnego przewidzianego $\mathrm{w}$ dyrektywie unijnej nie wydawały specjalnej ustawy poświęconej implementacji danego rozwiązania do prawa krajowego lub by nie ograniczały się do wydania tylko jednej takiej specjalnej ustawy, lecz by mogły implementować określone rozwiązanie prawne przewidziane w unijnej dyrektywie za pomocą pewnych swoich ogólnych (horyzontalnych) rozwiązań instytucjonalnych, które już w prawie krajowym tego państwa członkowskiego istnieją. Innymi słowy, dyrektywy unijne i przewidziane w nich instytucje prawne mogą być implementowane do prawa krajowego przez ogólne ramy prawne już istniejące $\mathrm{w}$ danym państwie lub przez ogólnie istniejący w danym państwie kontekst prawny, o ile te już istniejące rozwiązania krajowe odpowiadają wymogom skuteczności danej dyrektywy w krajowym porządku prawnym ${ }^{28}$.

W taki właśnie zróżnicowany sposób - wykorzystujący wskazane wyżej różne możliwości prawne implementowania dyrektyw unijnych - została w prawie polskim zaimplementowana sankcja nieskuteczności umowy unormowana $\mathrm{w}$ dy-

${ }^{27}$ Dz. U. z 2009 r. nr 223, poz. 1778.

${ }^{28}$ Zob. np. B. Kurcz, Dyrektywy Wspólnoty Europejskiej i ich implementacja do prawa krajowego, Zakamycze, Kraków 2004, s. 177 i n.; zob. też wyroki TSUE w sprawach: 163/82, Komisja przeciwko Włochom, ECLI:EU:C:1983:295, pkt 9; 29/84, Komisja przeciwko Niemcom, ECLI:EU:C:1985:229, pkt 22-23; 247/85, Komisja przeciwko Belgii, ECLI:EU:C:1987:339, pkt 9; 262/85, Komisja przeciwko Włochom, ECLI:EU:C:1987:340, pkt 9; C-96/95, Komisja przeciwko Niemcom, ECLI:EU:C:1997:165, pkt 35; C-217/97, Komisja przeciwko Niemcom, ECLI:EU:C:1999:395, pkt 31; C-214/98, Komisja przeciwko Grecji, ECLI:EU:C:2000:624, pkt 49; C-38/99, Komisja przeciwko Francji, ECLI:EU:C: 2000:674, pkt 53; C-49/00, Komisja przeciwko Włochom, ECLI:EU:C:2001:611, pkt 21; C-50/09, Komisja przeciwko Irlandii, ECLI:EU:C:2011:109, pkt 46; C-281/11, Komisja przeciwko Polsce, ECLI:EU:C:2013:855, pkt 60; C-648/13, Komisja przeciwko Polsce, ECLI:EU:C:2016:490, pkt 73. 
rektywach 89/665/EWG, 92/13/EWG oraz 2007/66/WE: otóż w zakresie naruszeń unijnych procedur dotyczących zamówień publicznych określonych w art. $144 \mathrm{i}$ art. 146 ust. 1 Pzp unijna sankcja nieskuteczności umowy została zaimplementowana w prawie polskim przez ustanowienie sankcji unieważnialności umowy w sprawie zamówienia publicznego, co nastąpiło w drodze uchwalenia specjalnie do tego przeznaczonej ustawy implementacyjnej ${ }^{29}$, natomiast w zakresie naruszenia wspomnianych unijnych procedur polegającego na ich całkowitym pominięciu i na udzieleniu zamówienia bez stosowania ustawy Pzp (czyli w zakresie tzw. bezprawnego bezpośredniego udzielenia zamówienia publicznego) unijna sankcja nieskuteczności umowy została w prawie polskim zaimplementowana przez odwołanie się (czy też poprzez dorozumiane odesłanie) do już istniejącej w prawie polskim sankcji bezwzględnej nieważności umowy przewidzianej w art. $58 \S 1$ k.c.; alternatywnie można też uznać, że sankcja bezwzględnej nieważności umowy w sprawie zamówienia publicznego przewidziana $\mathrm{w}$ art. $58 \S 1$ k.c. nie stanowi przejawu implementacji sankcji nieskuteczności umowy unormowanej w dyrektywach 89/665/EWG, 92/13/ EWG i 2007/66/WE, lecz stanowi przejaw implementacji obu dyrektyw przez zastosowanie w tym zakresie przez polskiego ustawodawcę surowszej sankcji, na co wprost dozwala pkt 20 preambuly do dyrektywy 2007/66/WE.

Warto przy tym zauważyć, że również w niektórych innych państwach członkowskich w omawianym tutaj zakresie zostało zastosowane rozwiązanie prawne analogiczne do tego przyjętego w prawie polskim, a mianowicie polegające na tym, że niezależnie od prawnej możliwości unieważniania umów w sprawach zamówień publicznych w ramach specjalnie stworzonego w tym celu systemu instytucjonalnego obejmującego określony wyspecjalizowany organ orzekający w sprawie środków ochrony prawnej wnoszonych przez wykonawców (w Polsce organem takim jest Krajowa Izba Odwoławcza) istnieje jeszcze możliwość odwoływania się w kwestii ważności umów w sprawach zamówień publicznych do sądów powszechnych orzekających na podstawie ogólnych reguł prawa cywilnego. Takie rozwiązanie istnieje m.in. w prawie duńskim, gdzie sądy powszechne mogą orzekać o nieważności umów w sprawach zamówień publicznych na podstawie ogólnych reguł prawa cywilnego (które zresztą są w tym zakresie znacznie surowsze niż przepisy przyjęte w Danii specjalnie w celu implementacji dyrektywy 2007/66/WE ${ }^{30}$ ), całkowicie niezależnie od kompetencji wyspecjalizowanego organu powołanego tam do rozpatrywania środków ochrony prawnej w zamówieniach publicznych ${ }^{31}$.

\footnotetext{
${ }^{29}$ A mianowicie nastąpiło to ustawą z dnia 2 grudnia 2009 r. o zmianie ustawy - Prawo zamówień publicznych oraz niektórych innych ustaw.

${ }^{30}$ Tzn. te ogólne duńskie przepisy prawa cywilnego są surowsze w tym sensie, że pozwalają one sądom powszechnym na stosowanie wobec umów w sprawach zamówień publicznych dalej idących sankcji anulacji umowy niż sankcje przewidziane w ustawie specjalnie przyjętej w Danii w celu implementacji dyrektywy 2007/66/WE.

${ }^{31} \mathrm{~S}$. Treumer, Enforcement of the EU Public Procurement Rules: Danish Regulation and Practice, [w:] Enforcement of the EU Public Procurement Rules..., s. 283-284.
} 
W omawianym tutaj kontekście warto byłoby jeszcze wskazać na dwa kolejne ważne prawne argumenty przemawiające za tym, że zastosowanie przez polskiego ustawodawcę sankcji bezwzględnej nieważności umowy w sprawie zamówienia publicznego zawartej bez stosowania ustawy Pzp stanowi przejaw prawidłowej transpozycji do polskiego porządku prawnego przepisów dyrektyw 89/665/EWG, 92/13/ EWG oraz 2007/66/WE, a więc że jest to rozwiązanie prawne w pełni zgodne z tymi dyrektywami. I tak, po pierwsze, rozwiązanie takie jest całkowicie zgodne z zasadą proporcjonalności - w tym sensie, że jest to przejaw zastosowania sankcji, której surowość jest jak najbardziej adekwatna do wagi wchodzącego tutaj w grę naruszenia prawa unijnego. W tym kontekście pkt $13 \mathrm{zd}$. 1 preambuły do dyrektywy 2007/66/ WE stanowi, że „Aby zwalczać bezprawne bezpośrednie udzielanie zamówień, które zostało uznane przez Trybunał Sprawiedliwości za najpoważniejsze naruszenie prawa wspólnotowego w dziedzinie zamówień publicznych ze strony instytucji zamawiającej lub podmiotu zamawiającego, należy przewidzieć skuteczne, proporcjonalne i odstraszające sankcje". Otóż należy uznać, że sankcja bezwzględnej nieważności zastosowana do umowy w sprawie zamówienia publicznego zawartej bez stosowania ustawy Pzp spełnia ów wspomniany wyżej wymóg proporcjonalności chociażby dlatego, że ta najsurowsza spośród znanych prawu polskiemu sankcji wadliwych czynności prawnych jest w tym przypadku stosowana do naruszenia Pzp o charakterze najdalej idącym. Jednocześnie w stosowaniu w przepisach Pzp zasady proporcjonalności w zakresie sankcji prawnych polski ustawodawca jest w pełni konsekwentny, jako że w przypadku naruszeń Pzp o mniejszej wadze (takich jak np. brak wymaganego ogłoszenia lub naruszenie reguł proceduralnych dotyczących trybów udzielania zamówień) polski ustawodawca nakazuje stosować do umów w sprawach zamówień publicznych łagodniejszą sankcję prawną w postaci unieważnienia umowy w sprawie zamówienia publicznego.

Po drugie, sankcja bezwzględnej nieważności umowy w sprawie zamówienia publicznego zawartej bez stosowania ustawy Pzp pozwala w sposób bardzo efektywny osiągnać cel sankcji nieskuteczności umowy przewidziany w dyrektywie 2007/66/ WE, jakim jest przywrócenie konkurencji i powrót danego zamówienia publicznego na rynek. O tego rodzaju celu sankcji nieskuteczności umowy w sprawie zamówienia publicznego jest wyraźnie mowa w pkt 14 zd. 1 preambuły do dyrektywy 2007/66/WE ${ }^{32}$. Nie można mieć wątpliwości, że bezwzględna nieważność umowy w sprawie zamówienia publicznego zawartej bez stosowania ustawy Pzp jest bardzo skutecznym środkiem powrotu danego zamówienia na rynek: umowa taka nie wywołuje ex tunc zamierzonych przez strony skutków prawnych, po deklaratoryjnym zaś potwierdzeniu (stwierdzeniu) przez sąd tej nieważności zamówienie publiczne

${ }^{32} \mathrm{~W}$ powołanym postanowieniu dyrektywy 2007/66/WE prawodawca unijny stwierdza, że „Nieskuteczność stanowi najlepszy sposób przywrócenia konkurencji i stworzenia nowych perspektyw handlowych podmiotom gospodarczym, które zostały bezprawnie pozbawione możliwości udziału w procedurze udzielania zamówień". 
stanowiące przedmiot tej nieważnej umowy może zostać przez danego zamawiającego ponownie udzielone, tym razem w ramach konkurencyjnego postępowania spełniającego wymogi określone w Pzp.

\section{Zakończenie}

W zakończeniu niniejszych rozważań należy podkreślić, że spór o rodzaj sankcji prawnych mających zastosowanie do umów będących zamówieniami publicznymi w rozumieniu Pzp i zawartych bez stosowania przepisów Pzp będzie z pewnością trwał, w tym również na gruncie przyszłej polskiej ustawy Prawo zamówień publicznych, której projekt został niedawno publicznie przedstawiony ${ }^{33}$. Przepisy wspomnianego projektu są bowiem w omawianym tutaj zakresie (tj. w zakresie sankcji cywilnoprawnych mających zastosowanie do umów w sprawach zamówień publicznych) w zasadzie identyczne treściowo z przepisami Pzp (zob. przede wszystkim art. 487 i art. 488 powołanego projektu). Gdyby wszakże polski ustawodawca (szczególnie w trakcie prac nad nową ustawą regulującą zamówienia publiczne) zdecydował się wyraźnie przesądzić, że umowy będące zamówieniami publicznymi (w znaczeniu normatywnym) zawarte $\mathrm{z}$ całkowitym pominięciem przepisów ustawy regulującej zamówienia publiczne są nieważne, względnie też gdyby tego rodzaju cywilnoprawna sankcja bezwzględnej nieważności została dopuszczona w takich sytuacjach przez praktykę stosowania prawa i orzecznictwo sądowe, to wówczas byłby to stan prawny w pełni zgodny z przepisami prawa unijnego regulującego zamówienia publiczne. Ani polskiemu ustawodawcy, ani też polskim organom stosującym Pzp nie można by w takiej sytuacji postawić zarzutu naruszenia przepisów prawa unijnego, w tym zwłaszcza przepisów dyrektyw 89/665/EWG, 92/13/EWG i 2007/66/WE. Sankcja bezwzględniej nieważności umowy zawartej bez stosowania ustawy Pzp może być bowiem alternatywnie uznana albo za przejaw (prawidłowej) implementacji sankcji nieskuteczności umowy przewidzianej w tych dyrektywach albo też za przejaw implementacji tychże dyrektyw przez zastosowanie przez ustawodawcę polskiego sankcji surowszej niż sankcja nieskuteczności umowy, na co powołane dyrektywy państwom członkowskim dozwalają.

\section{Literatura}

Besselink L.F.M., National and constitutional identity before and after Lisbon, Utrecht Law Review, 2010, vol. 6 .

Bovis C.H., EU Public Procurement Law, Cheltenham 2012.

Burgi M., EU Procurement Rules - A Report about the German Remedies System, [w:] Enforcement of the EU Public Procurement Rules, red. S. Treumer, F. Lichère, Copenhagen 2011.

\footnotetext{
${ }^{33}$ Zob. projekt ustawy Prawo zamówień publicznych w wersji z dnia 21 stycznia 2019 r., tekst dostępny na stronie: https://legislacja.rcl.gov.pl/docs//2/12320355/12565427/12565428/dokument378561.pdf.
} 
Cass D.Z., The word that saves Maastricht? The principle of subsidiarity and the division of powers within the European community, Common Market Law Review, 1992, vol. 29.

Chalmers D., Davies G., Monti G., European Union Law: Cases and Materials, Cambridge 2010.

Cloots E., National Identity in EU Law, Oxford 2015.

Emiliou N., Subsidiarity: an effective barrier against "the enterprises of ambition?, European Law Review, 1992, vol. 17.

Galetta D.-U., Procedural Autonomy of EU Member States: Paradise Lost? A Study on the "Functionalized Procedural Competence" of EU Member States, Berlin-Heidelberg 2010, passim. Gutowski M., Nieważność czynności prawnej, Warszawa 2017.

Hartley T.C., The foundations of European Union law, Oxford 2014.

Moens G.A., Trone J., Subsidiarity as Judicial and Legislative Review Principles in the European Union, [w:] Global Perspectives on Subsidiarity, red. M. Evans, A. Zimmermann, Dordrecht 2014.

Kakouris C.N., Do the member states possess judicial procedural "autonomy"?, Common Market Law Review, 1997, vol. 34, nr 6.

Kurcz B., Dyrektywy Wspólnoty Europejskiej i ich implementacja do prawa krajowego, Zakamycze, Kraków 2004.

Machnikowski P., Art. 58, [w:] Kodeks cywilny. Komentarz, red. E. Gniewek, Warszawa 2006.

Matei E., The Remedies Directive in Public Procurement, [w:] Research Handbook on EU Public Procurement Law, red. C. Bovis, Cheltenham 2016.

Radwański Z., Sankcje wadliwej czynności prawnej, [w:] System prawa prywatnego. Tom 2. Prawo cywilne-część ogólna, red. Z. Radwański, Warszawa 2002.

Safjan M., Art. 58, [w:] Kodeks cywilny. Tom I. Komentarz do artykułów 1-449 ${ }^{10}$, red. K. Pietrzykowski, Warszawa 2011.

Toth A.G., The principle of subsidiarity in the maastricht treaty, Common Market Law Review, 1992, vol. 29.

Von Bogdandy A., Schill S., Overcoming absolute primacy: Respect for national identity under the Lisbon Treaty, Common Market Law Review, 2011, vol. 48.

Wilman F., Private Enforcement of EU Law Before National Courts. The EU Legislative Framework, Cheltenham 2015.

\section{Akty prawne}

Wyrok TSUE w sprawie C-19/13, Ministero dell'Interno przeciwko Fastweb SpA, ECLI:EU:C: 2014:2194.

Wyrok TSUE w sprawie 163/82, Komisja przeciwko Włochom, ECLI:EU:C:1983:295, pkt 9; 29/84.

Wyrok TSUE w sprawie Komisja przeciwko Niemcom, ECLI:EU:C:1985:229, pkt 22-23.

Wyrok TSUE w sprawie 247/85, Komisja przeciwko Belgii, ECLI:EU:C:1987:339, pkt 9; 262/85.

Wyrok TSUE w sprawie Komisja przeciwko Włochom, ECLI:EU:C:1987:340, pkt 9; C-96/95, Komisja przeciwko Niemcom, ECLI:EU:C:1997:165, pkt 35; C-217/97, Komisja przeciwko Niemcom, ECLI: EU:C:1999:395, pkt 31.

Wyrok TSUE w sprawie C-214/98, Komisja przeciwko Grecji, ECLI:EU:C:2000:624, pkt 49.

Wyrok TSUE w sprawie C-38/99, Komisja przeciwko Francji, ECLI:EU:C:2000:674, pkt 53.

Wyrok TSUE w sprawie C-49/00, Komisja przeciwko Włochom, ECLI:EU:C:2001:611, pkt 21.

Wyrok TSUE w sprawie C-50/09, Komisja przeciwko Irlandii, ECLI:EU:C:2011:109, pkt 46.

Wyrok TSUE w sprawie C-281/11, Komisja przeciwko Polsce, ECLI:EU:C:2013:855, pkt 60.

Wyrok TSUE w sprawie C-648/13, Komisja przeciwko Polsce, ECLI:EU:C:2016:490, pkt 73.

Ustawa z dnia 29 stycznia 2004 r., tekst jedn. Dz. U. z 2018 r., poz. 1986 ze zm.

Ustawa z dnia 23 kwietnia 1964 r., tekst jedn. Dz. U. z 2018 r., poz. 1025 ze zm.

Ustawa z dnia 17 listopada 1964 r., tekst jedn. Dz. U. z 2018 r., poz. 1360 ze zm. 
Projekt ustawy Prawo zamówień publicznych w wersji z dnia 21 stycznia 2019 r., tekst dostępny na stronie: https://legislacja.rcl.gov.pl/docs//2/12320355/12565427/12565428/dokument378561.pdf.

Dyrektywa 2007/66/WE Parlamentu Europejskiego i Rady z dnia 11 grudnia 2007 r. zmieniająca dyrektywy Rady 89/665/EWG i 92/13/EWG w zakresie poprawy skuteczności procedur odwoławczych w dziedzinie udzielania zamówień publicznych, Dz. Urz. WE 2007, L 335/31.

Dyrektywa Rady 89/665/EWG z dnia 21 grudnia 1989 r. w sprawie koordynacji przepisów ustawowych, wykonawczych i administracyjnych odnoszących się do stosowania procedur odwoławczych w zakresie udzielania zamówień publicznych na dostawy i roboty budowlane (Dz. Urz. EWG 1989, L 395/33), zmieniona dyrektywą 2007/66/WE.

Dyrektywa 92/13/EWG z dnia 25 lutego 1992 r. koordynująca przepisy ustawowe, wykonawcze i administracyjne odnoszące się do stosowania przepisów wspólnotowych w procedurach zamówień publicznych podmiotów działających w sektorach gospodarki wodnej, energetyki, transportu i telekomunikacji (Dz. Urz. EWG 1992, L 76/14), zmieniona dyrektywą 2007/66/WE.

Dyrektywa Parlamentu Europejskiego i Rady 2014/24/UE z dnia 26 lutego 2014 r. w sprawie zamówień publicznych, uchylająca dyrektywę 2004/18/WE, Dz. Urz. UE 2014, L 94/65.

Dyrektywa Parlamentu Europejskiego i Rady 2014/25/UE z dnia 26 lutego 2014 r. w sprawie udzielania zamówień przez podmioty działające w sektorach gospodarki wodnej, energetyki, transportu i usług pocztowych, uchylająca dyrektywę 2004/17/WE, Dz. Urz. UE 2014, L 94/243. 